\title{
Modern Houses in a Folk Architectural Environment ${ }^{1}$
}

Received: May 29, $2020 \cdot$ Accepted: June 24, 2020

\author{
Ágota Lídia Ispán \\ Institute of Ethnology, Research Centre for the Humanities, Budapest
}

\begin{abstract}
From the 1960s, the hip-roofed, cube house became the dominant type of dwelling throughout Hungary. Architects and ethnologists raised objections to the resulting "alien" appearance of settlements, and eventually even the authorities attempted to slow down the spread of these dwellings, with little success. In the Örség region, with its characteristic folk architecture, the transformation was already visible by the 1970 s, despite the region having some of the worst socioeconomic conditions in the country. Before the establishment of the Örség Landscape Protection Area in 1978, the debates between the proponents of socialist modernization and those wishing to promote nature and the conservation of folk heritage were becoming increasingly heated. One such conflict was based on the difference of opinion between those wishing to preserve the architectural heritage, and the demands of local inhabitants for the modernization of their housing. In the present paper, in relation to the Örség region, and to a lesser extent Vendvidék (Porabje), I examine how the building stock was transformed, what means were used to try to prevent the spread of the modern cube houses, what plans were put in place to preserve the traditional architectural features of the region, and with what kind of new functions attempts were made to solve the utilization of old buildings.
\end{abstract}

Keywords: transformation of folk architecture, hip-roofed cub house, regionally appropriate standard designs

\section{INTRODUCTION}

Since the 1960s, the transformation of Hungary's built environment has continuously been a topic of public debate. Whether that debate centered on housing estates or cubeshaped village houses, recurring elements in the situational analysis were the lack of architectural variety; monotony and uniformity; along with problems arising from the structural distribution of dwellings and problems affecting lifestyle. As the ethnographer Péter Halász stated in 1969 in relation to contemporary rural architecture: "The houses

1 This study was supported by the Hungarian National Research, Development and Innovation Office, project number: NKFIH SNN 126230. 
being built today are ungainly, dull, and dreary, despite their often garish colors" (HALÁsz 1969:69). In 1975, the poet László Nagy criticized the absence of esthetic, contemporary, human architecture in his evocative image of housing estates: "As if a tenth-rate, sullen, commercialized, Bauhaus-concrete harridan had laid her spawn the length of our country" (NAGY 1975). The latter utterance was made in the context of one of the keenest polemics in relation to housing estates, fought in the columns of the weekly journal of literature and politics Élet és Irodalom [Life and Literature] (and subsequently, in professional circles, in the periodical Magyar Épitömüvészet [Hungarian Architecture]) in the wake of one attempt to relieve the monotony resulting from standardization - the decoration, with tulip motifs, of a large panel building near the Paks nuclear power plant (MOLNÁR 2005). The village houses that came to be known as "Hungarian cubes" gave rise to no such conceptual debate, although the role of the family house as a form of dwelling prompted lively discourse among architects and writers in the first half of the 1960s.

In the Socialist system, the alleviation of housing problems among the urban working class was prioritized, and public investments were used primarily for the construction of four-story or taller urban tenement flats, although in terms of both quantity and quality, these did not meet the standards of private housing construction (VALUCH 2013:95-97). Despite the fact that family houses were still the dominant form of dwelling in Hungary in 1949 (when $84.6 \%$ of dwellings belonged to this category), the country's post-war architectural elite - as highlighted in the research carried out by Márkus Keller did not promote this type of housing. Based on the predominantly modernist approach adopted by this elite, it was argued that family houses fell short of the ideal of owneroccupied flats, as they were less economical, provided more scope for the tastes of nonprofessional homeowners, were obstacles to communal life, and, ultimately, were not in harmony with the expectations of the evolving Socialist society (KELLER 2019:52, 54-55). The post-war architectural elite criticized - largely on the basis of esthetic considerations - the architectural solutions adopted by rural villagers, who typically made additions to the family homes built according to the cost-free, standard government designs that had been drawn up on the basis of a superficial understanding of rural life. The architects' concepts were dominant in newly built villages only (TAMÁSKA 2013:118124). State housing policy not only failed to pay due attention to rural areas during the allocation of investments, but it also provided less favorable loan conditions for housing construction and made loans available to a smaller number of workers in the agricultural sector in the 1950s (KELLER 2019:56-59). Despite these conditions, two-thirds of newly built houses between 1960 and 1980 were financed privately, most of them taking the form of family houses in villages, small towns, and suburbs (VALUCH 2013:98).

In contrast to the modern, vernacular, standard houses of the 1940s and 1950s (TAMÁSKa 2013:136), the hip-roofed, cube-shaped house became the dominant type of dwelling throughout Hungary from the 1960s. There are many theories regarding its origin: the detached houses based on a square ground plan that had been built before the war in workers' residential districts on the outskirts of towns may have served as a model (TAMÁSKa 2008:103; PraKFalvi 2015:293-295), although another possibility is that the cube house emerged via the development of the L-shaped village house (Kovícs 2017:104-105). Architects and ethnographers alike observed the spread of the cube house with antipathy, since, in their opinion, it destroyed the visual and structural harmony of the traditional village and introduced an alien type of dwelling that failed even to meet 
the needs of its inhabitants (MoLNÁR 2010:72-73). For new homeowners, however, the modern house - which was now their most important asset, having replaced land ownership in the wake of collectivization - also functioned as the symbol of a new, more comfortable, modern lifestyle, one that was distinguished from the peasant lifestyle and more closely aligned with their lower middle-class aspirations (JÁvor et al. 2000:994).

The competent authorities had little success in preventing the nationwide spread of the hip-roofed cube houses. In the Örség region, with its characteristic folk architecture, this transformation was already visible by the 1970 s, despite the region having some of the worst socioeconomic conditions in the country. Before the establishment of the Örség Landscape Protection Area in 1978, debates between the proponents of Socialist modernization and those who preferred to promote nature and the conservation of the folk heritage were becoming increasingly heated (Ispán 2019). One such conflict was based on the difference of opinion between those who wished to preserve the architectural heritage, and members of the local population who were demanding the modernization of their dwellings. ${ }^{2}$ In the present paper, in relation to the Örség region and, to a lesser extent, Vendvidék (Porabje), I examine how the building stock was transformed, what means were used to try to prevent the spread of the modern cube house, the plans that were put in place to preserve the traditional architectural features of the region, and the new functions that were proposed in an attempt to utilize old buildings.

\section{THE TRANSFORMATION OF THE BUILT ENVIRONMENT}

In the course of the $20^{\text {th }}$ century, the settlements in two ethnographical-historical regions in Vas County, on the southwestern border of Hungary, were preserved almost in the form of "relics", where modernization processes lagged behind the majority of the country and were more modest in comparison. This was partly due to the fragmented settlement structure, which hindered infrastructural development; the poor agricultural conditions in the settlements; and their unfavorable border location. This last difficulty was exacerbated under the Communist dictatorship by the fact that the region bordered the former Yugoslavia and Austria, necessitating strict border controls and the restriction of free movement - although these were eventually eased. ${ }^{3}$

In the Socialist era, settlement development concepts were also unfavorable with respect to this region. In 1951, the executive order on town and village planning classified settlements into three groups. Most of the villages in the examined region (and $47 \%$ of settlements in the country) fell into the non-development category, where only investments of local importance - that directly served the interests of production and basic public needs - were authorized (access roads, well drilling, primary schools, and telephone and electricity services). In these settlements, no building permits could be issued for residential buildings, and any construction planning was directed towards neighboring settlements of a higher rank. (HAJDÚ 1989:89; 1993:13-15). The 1971 National Settlement Network Development Concept also organized settlements hierarchically,

\footnotetext{
2 For a recent example of the conflict between the national park and local population, see: MÉszÁRos 2019:243-245.

3 For more about the region, see: IsPÁn et al. 2018.
} 
designating centers for development at each level from the top downwards, although the lower four levels were awarded only a tiny percentage of the development funds. Almost two-thirds of settlements fell into the category "not having a central role," thus not eligible for development. In these settlements, the institutional network was reduced, or it was merged with that of a central settlement (this so-called zoning covered schools, cooperative farms, medical services, the local state administration, etc.), while bans on construction were imposed in peripheral areas and residents had access to housing loans with less favorable terms in these types of settlements, contributing to their general decline and to population migration (KOCSIS - LENNER 2012:79-80; BELUSZKY 2011:55).

According to Máté Tamáska, after the Second World War the most rapid transformation in the building stock took place in the villages in the so-called depression zones (the Upper and Central Tisza regions, Göcsej, the central and southern parts of Fejér County, as well as the Örség region) - where the architecture was dominated by the archaic style of late$19^{\text {th }}$-century houses and where farming methods and architectural approaches were adapted to the landscape - since it was here that buildings became obsolete as a result of the rapidly changing living conditions (TAMÁSKA 2008:100-101). However, in the examined regions, the disadvantages of their peripheral situation - which overrode any aspirations toward modernity — was also reflected in the housing stock: in 1980, the majority of the existing buildings were pre-war constructions. In the villages of the Örség region, large numbers of new houses were constructed in the interwar period, as well as in the 1960s, while in the case of Vendvidék, the age distribution of dwellings was far less favorable. Even in 1980, most of the existing dwellings in the settlements of Vendvidék had been built before 1900, and far fewer new buildings were constructed after the war here compared to the Örség region (see Figure 1). Most of the dwellings in both regions comprised one or two rooms, and only a few had a proper bathroom or lavatory, although in this respect, too, the Örség region presents a more favorable picture than Vendvidék ${ }^{4}$ (see Figure 2).

In 1981, this delay in development was viewed positively in retrospect by the president of the Friends of Örség (a local "civil" society organization) for " "preventing the domination' of the featureless cube house" in the villages in Örség and enabling the region to participate in a "more exacting reconstruction process that is more closely aligned with tradition and, importantly, that is more appropriate to the landscape." ${ }^{\prime 5}$ At the same time, these settlements were not left entirely untouched by modernization, and where homeowners had the opportunity, they replaced old buildings with new ones, since the log buildings characteristic of the region proved impossible to modernize (Kovícs 2017:102103). The Building Department of the Szentgotthárd District Council was responsible for issuing demolition and building permits in the examined region. In $1963,{ }^{6}$ the department received several demolition applications - including for residential buildings, barns, and press-houses - from the Örség region and, less frequently, from settlements in Vendvidék. In each case, the application was based on the obsolete condition of the building - rotting wooden walls and dilapidated thatched roofs, which would have been uneconomical to refurbish. The houses in question were typically in such a poor state of repair that they

\footnotetext{
4 Author's calculation. Data source: Census of 1980. 1981:714, 702-703.

5 Vas Népe (daily newspaper published in Vas County), July 29, 1981. "Rambles in Örség” (6).

6 The documents of the Building Department of the Szentgotthárd District Council have been available in the archive since 1963.
} 


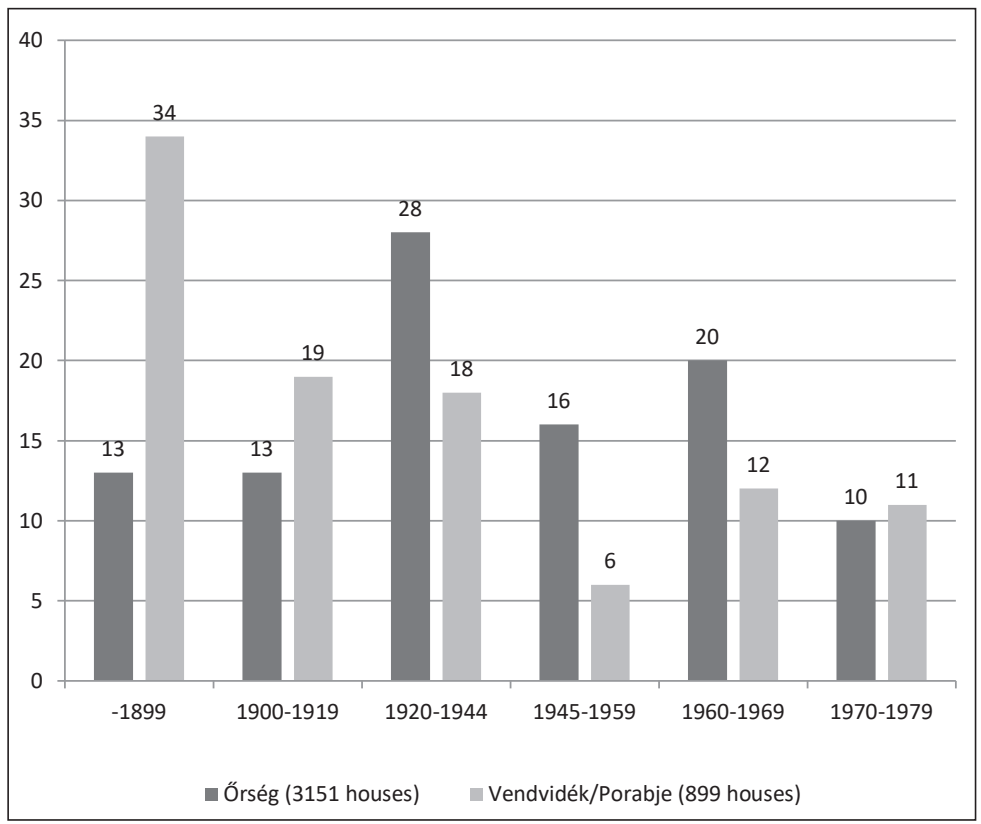

Figure 1. Distribution of the building stock (\%)

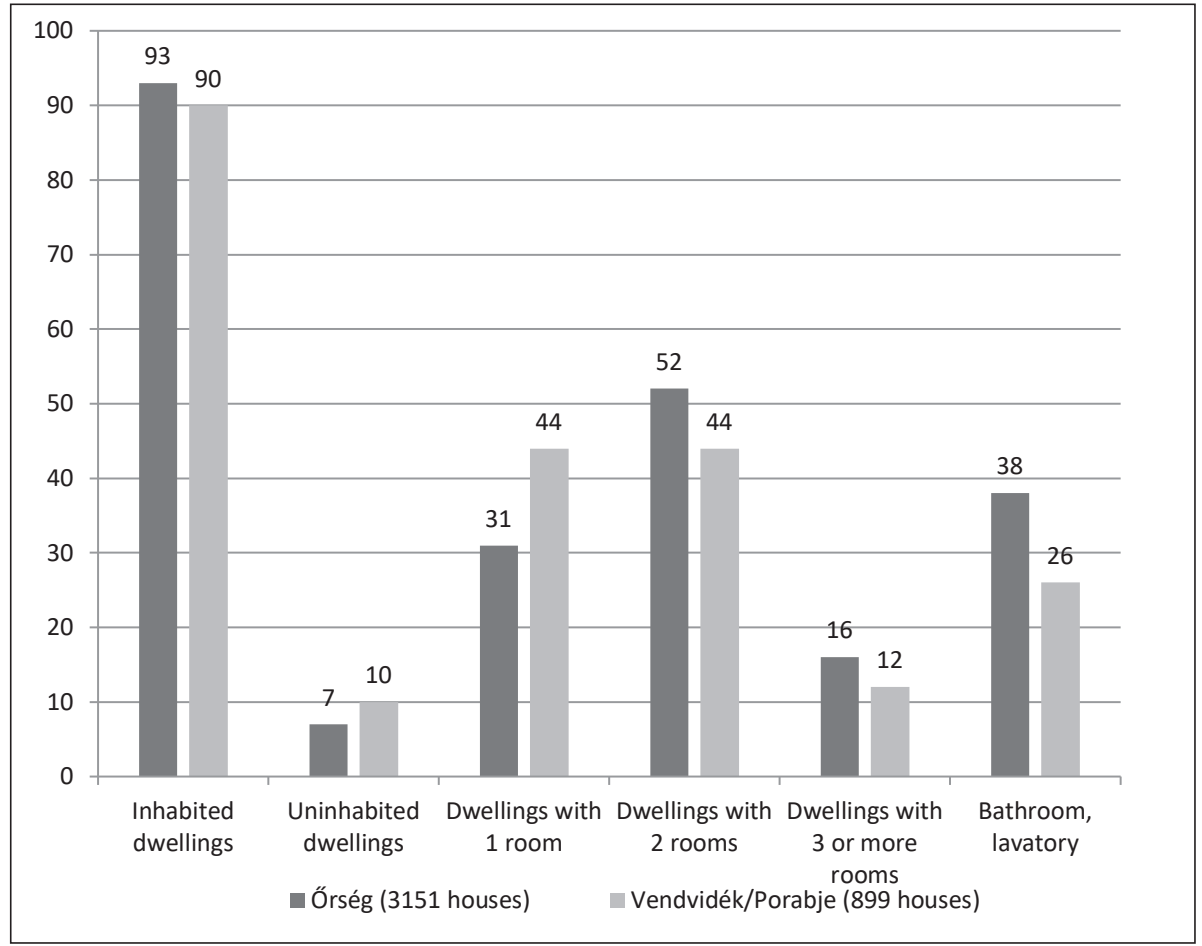

Figure 2. Characteristics of dwellings (\%) 

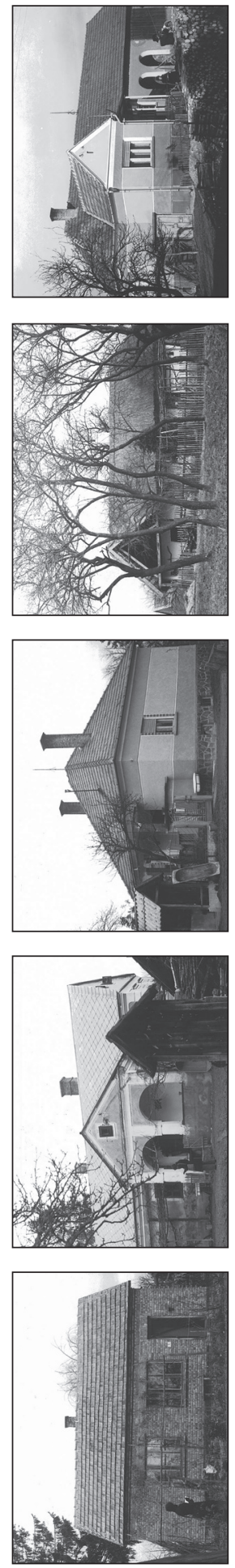
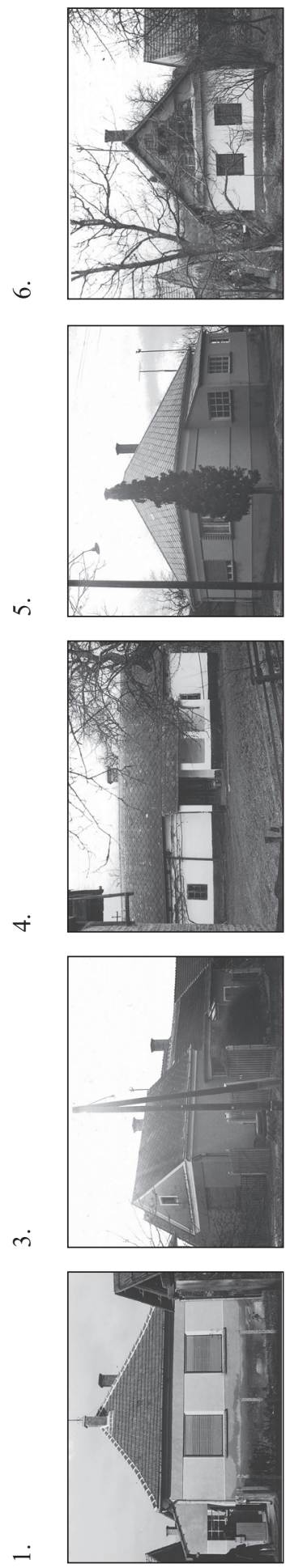
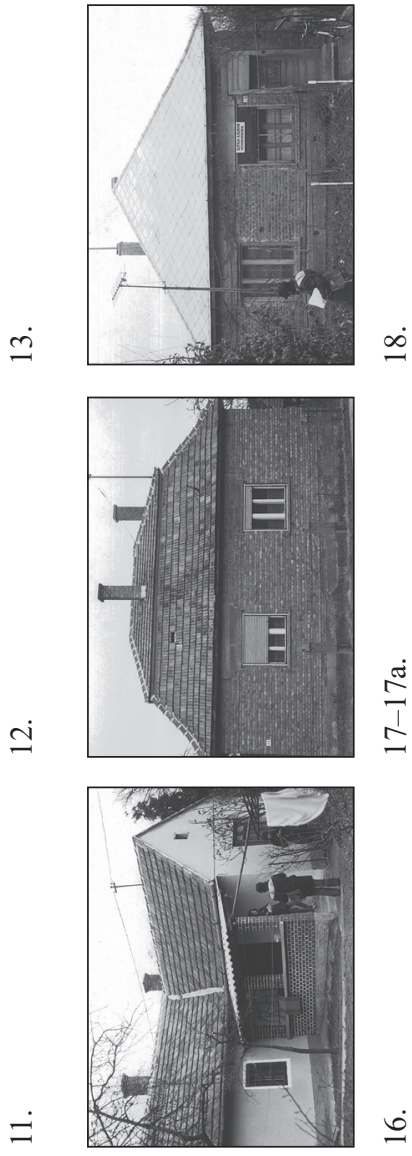

$\ddot{0}$
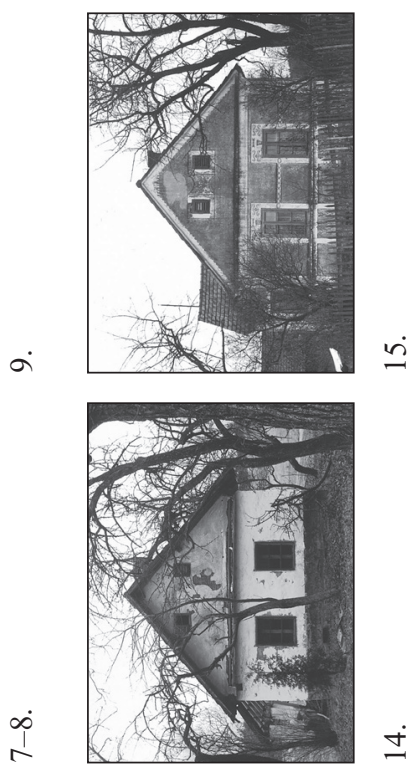

$\dot{ \pm}$ 

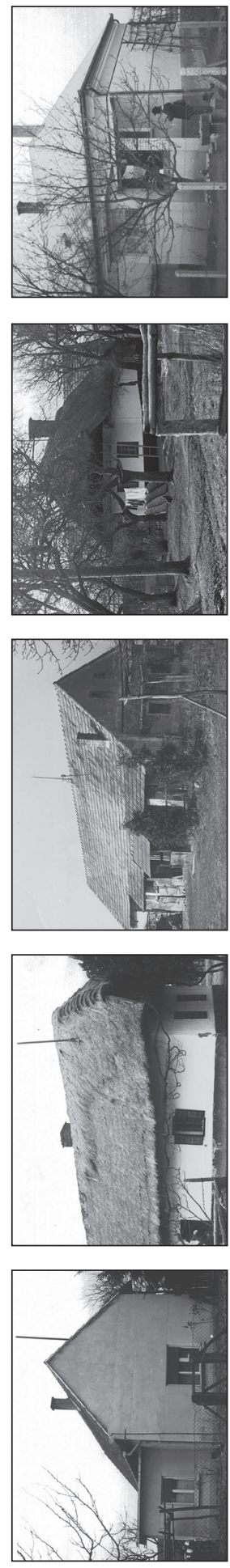
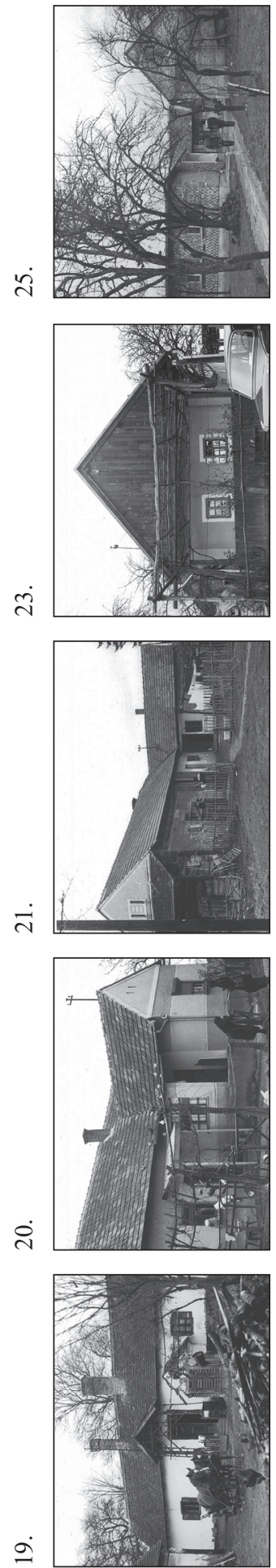

กี่
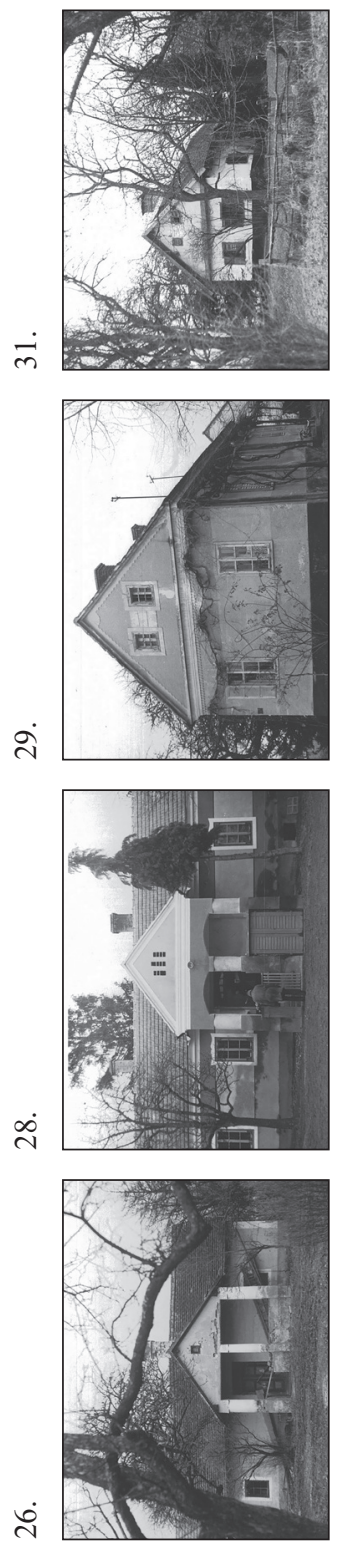

$\infty$
0
0
0
0
0
0
$\frac{\pi}{\pi}$
N
N

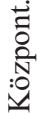

:0

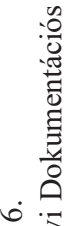

ஸें

$\stackrel{0}{:}$

괴

言岗

:

尝

的莺苛

in

这

के ले ले

ลू है की

:

Uें

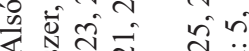

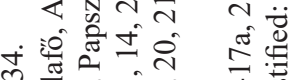
芯

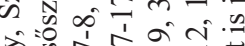

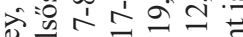
एक की on $\Xi \approx$ 홀

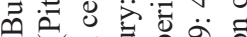

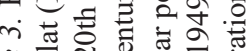
제

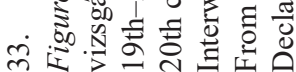




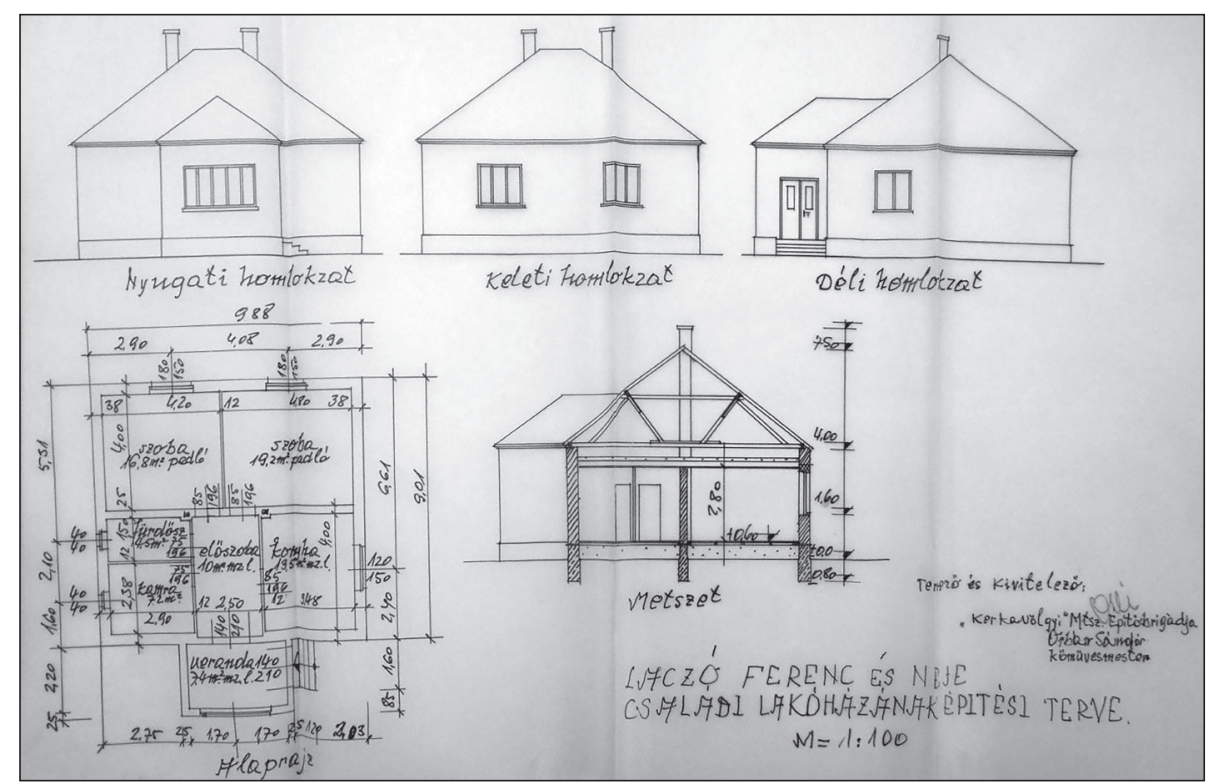

Figure 4. Construction plan for new residential buildings in Kondorfa, 1963. Source: MNL VAML XXIII. 314. 4. d. (Registration number: 11.439.)

were uninhabited, while the farm buildings were no longer in use as the owners were not engaged in agricultural activities, and it was hoped that the material from the demolition could be used to build new houses. The building authority automatically granted demolition permits, regardless of whether the houses had been built in the $19^{\text {th }}$ century or between the two world wars. In the case of listed buildings, the approval of the National Monument Inspectorate was also required, and was typically granted due to the dilapidated state of the buildings. ${ }^{7}$ As a result of the demolitions, the villages became more eclectic in appearance. This was striking even in Szalafo", a village still renowned for its folk historical buildings, where a comprehensive building survey was carried out in 1979 (see Figure 3).

In areas of historical significance, attempts were made to protect the characteristic appearance of a particular settlement primarily by means of building regulations formulated in the framework of settlement development plans, which often meant a ban

\footnotetext{
7 Magyar Nemzeti Levéltár Vas Megyei Levéltára [National Archives of Hungary Vas County Archives] (hereafter cited as MNL VAML) XXIII. 314. Executive Committee of the Szentgotthárd District Council. Documents of the Department of Construction and Transport. 1. d. 11. 028/1963. (Kondorfa); 11.090/1963 (Öriszentpéter, Baksaszer). If reconstruction nevertheless took place, strict regulations had to be observed. In connection with the demolition of a barn and a stable and the issuing of a permit for repairs to a dwelling, for example, the following constraints were imposed on the owners: "Beaver tail tiles can perhaps be purchased most easily from demolition sites, and the roof must be retiled in its present form - that is, with a jerkinhead design. We likewise agree that the verandas should be glassed in. (...) The glass must be fitted in such a way that the columns must be well visible from the courtyard - that is, the level of the glass must be kept to the middle of the thickness of the parapet wall, or even further back." 4. d. 11460-2/1963. (Rönök) The settlement is situated in the immediate vicinity of the examined region.
} 
on the construction of "alien" cube houses. This led me to undertake a more detailed analysis of the regulatory activities implemented by the state apparatus, along with their national context.

\section{ELEMENTS OF OFFICIAL REGULATION}

Initially, the regulations were aimed at raising professional standards among those engaged in private planning. Up until 1958, anyone had had the right to design family houses, but from that date on, permits were granted exclusively to professionals whose names were included in the National Register of Planners compiled by the Ministry of Construction and who had received appropriate training. ${ }^{8}$ Amendments were introduced in 1967, in the form of further differentiation among authorized planners. ${ }^{9}$ Based on a decree issued by the Ministry of Construction - and in the context of efforts towards decentralization - the National Register of Planners was replaced by a register of planners compiled by the county authorities. Authorized private individuals were classified into four categories, on the basis of which they were permitted to design different types of buildings. Category A: architects or civil engineers; category B: master builders or construction industry technicians with higher-level qualifications; category $\mathrm{C}$ : graduates of construction technology schools or construction industry technicians, who were permitted to design houses with a maximum of two stories; and category D: in exceptional cases, qualified master masons were permitted to design single-story houses only. ${ }^{10}$ According to a newspaper article published in 1973, those belonging to category $\mathrm{C}$ - due to their large number and their proximity to rural clients - "truly dominated the field" with respect to rural home construction, although in terms of their training they were qualified primarily for practical building work, while members of category D - although similarly numerous - were not significantly involved in planning work, and, if they did do any planning, "the majority of their plans were fairly rudimentary, of poor quality, and lacking in taste."11 While an architect would draft four or five plans a year, a technician or mason would draft 30 to $40 .{ }^{12}$

In Vas County - where the two small regions are situated - 187 private planners were listed in 1970: of these, 54 were architects and construction engineers, 90 were construction technicians, and 43 were master masons. Since only a small proportion of architects were involved in designing family houses, most of the commissions were given to building technicians, who worked according to commercial serial designs or individually tailored standard designs, regarding which the head of the county council construction department expressed a contemptuous opinion: "Based on many years of

8 Magyar Közlöny [Official gazette of Hungary], October 29, 1958, no. 100. Decree no. 3/1958 (Oct. 29) É. M. of the Minister of Construction on the Planning of Non-public Buildings.

9 Délmagyarország [daily newspaper of southern Hungary], November 15, 1973. "Magánügy-e a magánház? Tervek és tervezők" [Are private houses a private matter? Plans and planners].

10 Magyar Közlöny [Official gazette of Hungary], April 9, 1967, no. 21. Decree no. 2/1967 (April 9) É. M. of the Minister of Construction on Private Planning Activities.

11 Délmagyarország [daily newspaper of southern Hungary], November 15, 1973. "Magánügy-e a magánház? Tervek és tervezők" [Are private houses a private matter? Plans and planners].

12 Magyar Nemzet [Hungarian daily newspaper], January 30, 1976. "A magánlakásépítés Szolnok megyében" [The construction of private dwellings in Szolnok County]. 
experience, and having examined thousands of designs, it is fair to say that the vast majority of family houses that have been built on the basis of designs to date, with the consumption of a great deal of material, energy, and private and government funds, are primitive even compared to the average residential construction culture of Central Europe, and were already outdated at the time they were built." Among the factors that had a negative impact on the quality of the designs, he mentioned a lack of interest in housing design on the part of homeowners, indifference to architecture and ignorance on the part of society, and inadequate public information. From a planning perspective, he emphasized the low level of professional training among the majority of private planners and construction authority personnel, and a lack of sophistication in terms of the selection of building materials; while in relation to the execution of the designs, he referred to the dominance of master masons and its direct impact on homeowners. This resulted in builders modifying accepted designs in the course of construction - the outcome of which could be seen in the look of the building facades; in "over-ornate, kitsch, and unharmonious" spatial proportions; and in the heightening of buildings. ${ }^{13}$

This enhanced the importance of the activities of private planning expert committees, the establishment of which had also been made possible by the 1967 decree in the case of the responsible second-level construction authorities (this typically meant the construction departments of the county councils), since their objective was to raise technical standards and promote the professionalism of private planning. These committees - which were made up of architects - examined the basic technical, functional, and esthetic value of the designs and were obliged to issue a response within 15 days, although their decisions were merely recommendations rather than being mandatory. ${ }^{14}$ Their activities prompted a great deal of controversy: as early as 1970, the chair of Vas County Council, for example, argued for them to be abolished, despite the fact that the first-level district authorities lacked appropriately trained staff at the time, and that the district, city, and other municipal leaders had a positive opinion of them..$^{15}$

In the general experience of these committees, the plans that were submitted for approval were of a poor standard both technically and in terms of their compilation, and failed to meet even the minimum requirements of the National Building Code. The most common errors were as follows. ${ }^{16}$ In terms of the distribution of the living space: 1 . the inclusion of "cul-de-sac rooms" - that is, rooms that opened into each other, with no separate entrance - which ignored family requirements; 2 . every room in the house,

13 MNL VAML XXIII. 52. Meeting of the executive committee of the Vas County Council, February 23,1971 . Submission of observations on the construction of family houses.

14 Magyar Közlöny [Official gazette of Hungary], April 9, 1967, no. 21. Decree no. 2/1967 (April 9) É. M. of the Minister of Construction on Private Planning Activities.

15 MNL VAML XXIII. 52. Meeting of the executive committee of Vas County Council, April 21, 1970. Report on the activities of the construction authorities and the situation of the construction administration.

16 Nógrád [county newspaper], July 6, 1967, "Római egyes, kettes, hármas..." [Roman one, two, three...]; Heves Megyei Népújság [Heves County newspaper], February 25, 1968, "Milyen családi házat építsünk? Cifra rangosság - gazdaságos korszerúség” [What kind of family house should we build? Ornamental prestige - Economical modernity]; Pest Megyei Hirlap [daily newspaper of Pest County], May 9, 1969, “Korszerübb, olcsóbb lakások. A második év küszöbén a magántervezési szakértői bizottságok" [More contemporary, lower-cost dwellings. Private planning expert committees at the start of their second year]. 
including even the bathroom, opened from the kitchen; 3. the fireplace was typically placed where it hindered free movement; and 4 . both rooms were built on the northern side, merely to give the house a more elegant appearance from the street. Costly and bad solutions: 1 . the frequent raising of the floor level in family houses by two and a half meters (to compete with the neighbors), the cost of which would cover the installation of all the public utilities; 2 . unreasonably thick partition walls; 3 . redundant chimneys; and 4. structures that were wasteful in terms of both materials and labor. Esthetic criticisms: 1. costly and unsightly false mansards; 2 . ill-proportioned doors and windows; 3 . facades with tasteless decorative elements, etc.

A conceptual debate arose regarding the extent to which the building of a private dwelling was a purely private matter, and the extent to which committees had the right to interfere in questions of taste, since the general attitude among homeowners was that they were allowed to build whatever they wanted at their own expense. From a professional point of view, the responsibility of planners was emphasized. Underqualified planners were often criticized for going along unquestioningly with the non-expert ideas of homeowners that had merely been roughly sketched in a squared notebook. ${ }^{17}$ Planners were also criticized for using over-mechanized, mass-produced, essentially identical "individual standard designs." As one newspaper article put it: "A qualified architect should be something of an educator. Before getting down to designing a house, the architect needs to get to know the family, their circumstances, how the different members of the family are employed, and what their interests are, and the advice given should be based on this information." 18 Although the committees were frequently criticized for slowing down permitting procedures, and although they were abolished for years in several counties, including Vas County, their activities ultimately contributed to improving the quality of designs. As reported in the press, they "influenced the demand for civilized, modern homes, improved public taste, and reduced the number of uneconomic designs." 19

Overall, by the mid-1970s, favorable changes were perceptible in terms of rural public taste in the press: "the turrets, tin ornaments, and unattractive embellishments that had earlier been seen on newly built houses" were becoming less typical. ${ }^{20}$ Nevertheless, during the actual construction work there were often deviations from the plans: the internal proportions of rooms were changed, the kitchen and bathroom were swapped, or the building was enlarged - thus supervision during construction was considered highly important, although council building departments lacked the

17 Pest Megyei Hirlap [daily newspaper of Pest County], May 9, 1969, "Korszerübb, olcsóbb lakások. A második év küszöbén a magántervezési szakértői bizottságok" [More contemporary, lower-cost dwellings. Private planning expert committees at the start of their second year].

18 Délmagyarország [daily newspaper of southern Hungary], November 15, 1973, "Magánügy-e a magánház? Tervek és tervezők" [Are private houses a private matter? Plans and planners]; Nógrád [county newspaper], July 6, 1967, "Római egyes, kettes, hármas..." [Roman one, two, three...]

19 Magyar Nemzet [Hungarian daily newspaper], December 29, 1975, "Lakásépítés Csongrád megyében" [Housing construction in Csongrád County].

20 Népszabadság [daily newspaper], December 31, 1975, "Milyen házakat építsünk falun? Ankét a Népszabadság szerkesztöségében" [What kind of houses should we build in the village? Conference in the editorial office of Népszabadság]; Tükör [an illustrated literary monthly journal], October 28, 1975, “Az én házam: Tehet-e többet a hatóság?” [My home: Could the authorities do more?] 
necessary capacity. ${ }^{21}$ The construction authority - according to an assessment undertaken by Vas County Council in 1970 - was unable to "prevent the tendency toward deviations from the plans, the proliferation of unregulated extensions, and the construction of unauthorized outbuildings that ultimately result in the chaotic and irregular appearance of the settlement, and in constructions that have an adverse impact on living conditions." Fines and other penalties proved ineffective, while tougher sanctions (such as refusal to grant an occupancy permit, or the withdrawal of a permit) were not imposed due to welfare policy considerations. As already mentioned, the issuing of permits, "rather than exerting an active, progressive influence and representing healthy and moderate criticism, is instead a passive routine administrative activity." According to the chair of the county council, the construction authority always communicated with the homeowners rather than with the planners and builders, although the latter would be a better solution, as more effective sanctions could be imposed in their case: planners who were not familiar with the regulations should be deleted from the register of planners, while building contractors should be held responsible for adhering to the plans. ${ }^{22}$

In general, the standard designs were expected to improve construction culture, which, according to the authorities and professionals, meant a good layout, modernity, economical structural solutions, and professionalism. ${ }^{23}$ These standard designs were compiled in a variety of ways. The Private Housing Program Committee of the Ministry of Construction and Urban Development, for example, produced catalogs of plans that took regional character into consideration, ${ }^{24}$ while some county councils collaborated with the Ministry of Construction and Urban Development in issuing tenders for regional or local family house planning. ${ }^{25}$ The 19 plans prepared by the Bács-Kiskun County Planning Company in 1973, based on the unique features and architectural traditions of the county's settlements, nevertheless proved popular throughout the country and received huge publicity. ${ }^{26}$ Strong emphasis was given to popularizing them and to providing advice in relation to the construction of private homes, while homeowners who opted to follow the standard designs were given preferential treatment when determining the amount of building loans. ${ }^{27}$

21 Similar problems are addressed in: VMNL XXIII. 52. a. Minutes of the executive committee of the county council, April 21, 1970. Report on the activities of the construction authorities and the situation in the construction administration.

22 MNL VAML XXIII. 52. a. Meeting of the executive committee of Vas County Council, April 21, 1970. Report on the activities of the construction authorities and the situation of the construction administration.

23 Pest Megyei Hirlap [daily newspaper of Pest County], May 9, 1969, "Korszerübb, olcsóbb lakások. A második év küszöbén a magántervezési szakértői bizottságok" [More contemporary, lower-cost dwellings. Private planning expert committees at the start of their second year].

24 Magyar Nemzet [Hungarian daily newspaper], November 15, 1972, “Tervkatalógus a magánlakás építőknek" [Design catalog for builders of private dwellings].

25 Magyar Nemzet [Hungarian daily newspaper], May 30, 1975, “A családiház-tervpályázatok célja, eredményei" [Objectives and outcomes of family house planning tenders].

26 Petöfi Népe [daily newspaper of the Danube-Tisza Interfluve region], June 24, 1973, "Szervezett segítség az építtetőknek. A választék: 19 korszerü terv" [Organized assistance for homeowners. The choice: 19 modern plans].

27 Magyar Nemzet [Hungarian daily newspaper], January 30, 1976, "Elönyben a csoportos családiház" [Collective family houses take the advantage]. 
In the district in which our two regions are located, the question of standard designs emerged in 1970, in the context of a dispute. Based on meeting minutes, it appears that the construction authority had introduced a ban of some kind on hip-roofed houses, preferring the regionally characteristic gable. However, this practice was reviewed following an objection by members of the council, who demanded a more flexible approach on the part of the authority in terms of the application of building regulations in the permitting process. The question of the settlements in the Örség region also arose here. According to one member of the municipal executive committee, long-term development plans were also required for the villages, even though it was impossible to create attractive village centers due to their being so widely dispersed. A significant proportion of the buildings were outdated, while, in the case of new constructions, the councils "faced an uphill battle" to promote the construction of firewalls (gables). In the interests of improving building standards, the executive committee of the district council recommended the creation of a standard design for a contemporary family house, along with its construction in order to function as a model for the district's two large villages (Körmend and Szentgotthárd). By comparison, in the case of the Örség settlements, a constraint was already in place: the district building authorities had been requested to come up with a design for a contemporary family house appropriate for the character of the Örség landscape, which they were obliged to recommend to private homeowners, and which it was compulsory to use in the case of state investments. ${ }^{28}$ The two-story building that housed the council, the office of the Party, the post office, and the office of the Patriotic Popular Front alliance in Öriszentpéter was subsequently pointed out as a positive example: a "clean, modern building that is still in keeping with the landscape."

However, standard designs that were in keeping with the landscape had arrived too late. According to the architectural survey carried out in Öriszentpéter and the surrounding settlements in 1979, the new houses - depending on the settlement, and the specific part of the settlement - were based on different designs, structures, and roof forms, and were even characterized by the use of different materials, colors, and surface treatments on the facades, giving the settlements a disorderly appearance that was alien to their surroundings. As they saw it, the differing financial background and ample choice of standard design collections gave broad scope for the type of buildings that could be constructed. "The paradoxical situation can arise where a street lined with those same hip-roofed cube houses that earlier elicited so much criticism is nevertheless more attractive in appearance than individual standard houses built next door to each other" (GAZDA - MUSZIK 1979:4).

It was also hoped that the creation of village master plans would contribute to the development of a more modern village look. According to the 1970 assessment by the Körmend District Council, only a very few villages had such plans, although in places where they did exist, the population was far more aware of building-related requirements. ${ }^{29}$

28 MNL VAML XXIII. 226. a. Minutes of the meeting of the executive committee of the Körmend District Council, December 23, 1970. Report to the meeting of the executive committee of the Körmend District Council on the work of the construction and transport group. January 22, 1971, resolutions no. 11-15/1971.vb.

29 VMNL XXIII. 52. a. Minutes of the executive committee of the county council, April 21, 1970. Report on the activities of the construction authorities and the situation in the construction administration. 
The master plan for Szalafö was drawn up in 1975 and was based on surveys going back many years, carried out by the National Monument Inspectorate as well as the staff of the Institute of Urban Planning (architects, garden designers, sociologists), the goal of which, besides the identification of buildings meriting individual protection, was the designation of the future field of activity in the region, and more specifically in Szalafö; the direction the development should take; as well as the architectural framework for the transformation of the villages (KомJáthy 1985:89). Similarly complex surveys - which also explored the social processes behind settlement development - were carried out in relation to Öriszentpéter and the neighboring settlements, as well in settlements with a Slovenian population.

According to the architects who carried out the survey, with the disappearance of former production methods, and with extended families no longer living together, the old style of household had also become redundant. The appearance of fences, along with buildings that were larger than requirements, was seen as an indication of the growing predominance of individual interests over interdependence. The preservation of the traditional settlement structure was considered possible only where buildings were gradually being left empty due to the aging of the population, and thus the uniformity of the building complexes and their environment, and the protection of the landscape, could be ensured (e.g. the Pityerszer area of Szalafo"). The expected result would be "the establishment of a building reserve, a museum environment, from which the continuity of life would be absent" (GAZDA - MUSZIK 1979:16).

Besides protection, the fundamental aim of historic building conservation is to keep the buildings in contemporary use. However, in the case of folk historical buildings $\mathrm{s}^{30}$ - which were built to meet the needs of an earlier lifestyle - a change in function is made even more difficult by loss of function and technical devaluation (HARLOv 2016:120, 124). The preservation of historical buildings that were under individual protection and in private ownership proved to be a particularly difficult task, since sooner or later the owners wanted to modernize them. ${ }^{31}$ At the suggestion of the Historic Buildings Inspectorate, in 1971 a law was passed regarding the maintenance of protected folk buildings, which was further refined in 1974. According to this law, owners received an annual grant for the

30 The protection of folk architectural monuments was for many years a neglected aspect of the conservation of historic monuments and was only regulated by law in 1949 (BARCZA 1977:71). In the 1950 s, their topographical exploration also began, carried out primarily by architects, ethnologists, and museologists (FüZES 1997:321-322). As a result of exploratory work, the number of protected folk buildings approached 2,000 in 1968, although the list was soon narrowed down to fewer than 1,000 , since their protection was unrealistic at a time when the villages were undergoing rapid transformation (BARCZA 1977). The highest level of local protection was the protection of groups of folk historical monuments, the first example of which was Hollókö, which was later included in the UNESCO list of World Heritage sites. Since regional-level protection was rather costly (in terms of both modernization and maintenance), only limited numbers of such regions were designated. Two of the seven parts of the village of Szalafö in the Örség region were given protected status as historic monument ensembles as early as the 1960s (ТótH 1966:92-93), although this was only implemented in practice in 1987.

31 Their significance was enhanced by the fact that there were a far greater proportion of them compared to other forms of ownership. At the beginning of 1977 , around $78 \%$ of the 1,204 protected folk architectural monuments were in private ownership (approx. 17\% were managed by the state and cooperatives, and 5\% by the church) (BARCZA 1977:85). 
maintenance of their buildings, and were entitled to case-by-case support. Overall, the burden on owners was reduced and a process was launched, thanks primarily to the more well-to-do (chiefly intellectual) strata, in which buildings in private ownership were utilized for recreational purposes (BARCZA 1977:79-80). Based on the experience of the village of Hollókő with respect to the care of historic buildings, the utilization of buildings for public purposes (as museums, tourist accommodation, handicraft workshops, restaurants, kindergartens, or the headquarters of parties or organizations) was an additional solution that could be realized in the case of buildings that had come into state ownership (Tо́тH 1966:92; HARLOV 2016:124-125). In relation to the growth in tourism and the lack of tourist accommodation, as early as 1970 the district government realized that uninhabited or cheap folk historic buildings could be transformed into guesthouses for tourists, or could be sold for use as artists' studios or holiday homes. ${ }^{32}$

In the remaining settlements and settlement areas, however, the goal was to introduce settlement development regulations that contributed to the development of contemporary architecture based on tradition and adapted to the surrounding environment. In relation to Öriszentpéter and the neighboring settlements, as a fundamental principal in the interests of protecting the details of the characteristic settlement structure, it was recommended, for example, to maintain the road network, road routes, smaller open spaces, road widenings, crossroads, and footpaths; not to reduce the width of building plots; as far as possible not to use fencing, the appearance of which had just started to spread - or, where fences did exist, to have them made of wood and not too close-set; to have the walls of buildings painted white wherever possible; and, in the absence of thatch, to have the roofs tiled if possible (GAZDA - MUSZIK 1979). The master plan in Szalafó contained even stricter regulations: neither flat roofs nor buildings with more than one story were permitted in the village, nor was the construction of solid fencing allowed; in fact, the storage of pebbles, sand, and other materials was only permitted in the locations designated in the plan.

Following the creation of the landscape protection area in 1978, the Nature Protection Office also became responsible for the management of the central village areas. According to one of the regulations it introduced, in terms of the external appearance of the buildings in the settlements, the architectural features employed had to be appropriate to the character of the landscape; a contribution had to be made to the preservation of historical buildings and buildings that were valuable in terms of the look of the village; and, furthermore, efforts had to be made to preserve the traditional architectural character of Apátistvánfalva, Öriszentpéter, and Szalafö, for which a master plan had to be drawn up with the approval of the office. ${ }^{33}$

This objective was also reinforced by the "civil" society organization founded in the region in 1980 as a local intellectual initiative — the Friends of Örség — the tasks of which included cooperation on the elaboration of organizational and development programs;

32 MNL VAML XXIII. 226. a. Minutes of the meeting of the executive committee of the Körmend District Council, September 4, 1970. Historical monuments, museums, and nature conservation in the district.

33 Decision no. 4/1978 OKTH of the chair of the National Office for Environment and Nature Conservation on the establishment of the Örség landscape protection area. Tanácsok Közlönye [Council gazette], 1978, 27, 22, 548. 
and the protection of traditions, regional character, folk architecture, and ethnographical heritage. Awareness raising among the local population was considered as being of decisive importance in achieving this. ${ }^{34}$ Advice and geodetic surveys were provided free of charge for homeowners in the Örség region, for example, in order to ensure that "the houses built were appropriate to their surroundings, while still being contemporary." 35 A decisive role was played by the chair of the local council in Öriszentpéter, who also chaired the Friends of Örség and who was particularly active in terms of protecting the regional character of Örség. According to the regulations, it was compulsory to use red slate for roofing in the settlement. However, due to difficulties in supply, this was not always possible to obtain and was also more expensive than gray slate. In this instance, the council tried to help by agreeing to pay the difference in price. ${ }^{36}$ It took similar action against the frequently criticized "tasteless and ostentatious multicolored and overly ornamental fences, which spoiled the harmony of the old buildings" ${ }^{\prime 37}$ by supplying wood and brown slate for fence building at preferential prices. Even the national press regarded this particular example, as well as the initiatives of the Friends of Örség, as a model to be followed.

\section{SUMMARY}

The transformation of the built environment accelerated during the Socialist period, which, in the villages, resulted primarily in the spread of hip-roofed cube houses. Architects and ethnologists alike spoke out against the standardized appearance of the settlements, but with little success. Eventually, the authorities attempted to put a stop to this increasingly widespread process. This involved trying to improve professional standards among those involved in private planning: in order to overcome professional shortcomings, expert committees were established, which operated at territorial level, to oversee architectural planning. The promotion of standard designs was also expected to lead to an improvement in architectural quality, as were the general and detailed master plans that were drawn up for the villages from the 1960s. Overall, however, these measures were merely introduced in the wake of an already established situation.

In the examined borderland area, the transformation of the building stock took place more slowly due to the area's marginalization and isolation, while there was also a significant proportion of protected folk buildings. While the demolition of old log buildings and their replacement with cube houses in line with the national trends had begun in the 1960s with scarcely any control on the part of the authorities, the protection of the region's architectural character took place in a more organized manner in the 1970s. As part of this, attempts were made to come up with new uses for the historical buildings: they began to be bought up by the state and were given an educational function,

\footnotetext{
34 Vas Népe [daily newspaper published in Vas County], September 21, 1980, no. 5. "Örségi baráti kör alakult" [Creation of the Friends of Örség].

35 Vas Népe [daily newspaper published in Vas County], March 18, 1987, “Örségi Vásár" [Örség Fair].

36 Vas Népe [daily newspaper published in Vas County], December 7, 1983, "Körmendi magánépítök gondjai" [Problems faced by private builders in Körmend].

37 Magyar Nemzet [Hungarian daily newspaper], February 23, 1978, "Faluépítők" [Village builders].
} 
while utilization for recreational purposes also became increasingly widespread in the case of buildings in private ownership. Efforts were made to achieve a contemporary yet regionally appropriate village look by designing modern dwellings that were adapted to the landscape, and by including regulations in the village master plans that would protect the structure of the settlement. From the 1980s, active awareness raising work began among the local population on the necessity and value of such efforts, with the cooperation of "civil" service organizations established by the intellectual class.

\section{REFERENCES CITED}

1980. évi népszámlálás

1981 1980. évi népszámlálás 18. Vas megye adatai. [1980 census. Data of Vas County]. Budapest: Központi Statisztikai Hivatal.

BARCZA, Géza

1977 A népi építészeti emlékek védelme [The Protection of Folk Architectural Monuments]. Müemlékvédelem 21(2):71-85.

BÁRDOSI, János

1977 Anépi mủemlékek mentési módszerei, eredményei és tanulságai Vas megyében [Methods, Results, and Lessons in the Preservation of Folk Architectural Monuments in Vas County]. Életünk 15(4):353-359.

BeLuszky, Pál

2011 Tájsoroló - „Szükmarkú, szép föld - az Örség” [Landscape Classification — "An Ungenerous, Beautiful Land — the Örség"]. Földrajzi Közlemények 135(1):45-58.

FüZES, Endre

1997 A népi építészeti emlékek védelme [The Protection of Folk Architectural Monuments]. In BALASSA, Iván (ed.) Magyar néprajz IV. Életmód, 309-325. Budapest: Akadémiai.

GAZDA, Anikó

1977 Vas megye szlovének lakta községeinek települési és építési sajátosságai [Distinctive Settlement and Architectural Features of Slovene-Inhabited Villages in Vas County]. Budapest: VÁTI, IV. Mủemléki és Építéstervezési Iroda. (Lechner Tudásközpont - Dokumentációs Központ).

GAZDA, Anikó - MusziK, Lászlóné

1979 Öriszentpéter és a környező települések településtörténeti, szerkezeti és településkarakter vizsgálata [A survey of the settlement history, structure, and settlement character of Öriszentpéter and the neighboring settlements]. Budapest: VÁTI. (Lechner Tudásközpont - Dokumentációs Központ).

HAJDÚ, Zoltán

1989 Az első „,szocialista” településhálózat-fejlesztési koncepció formálódása Magyarországon (1949-1951) [The Shaping of the First "Socialist" Settlement HaLÁsz, Péter

Network Development Concept in Hungary]. Tér és Társadalom 3(1):86-96.

1969 Falusi építészet - megoldatlan kérdések [Village Architecture - Unanswered Questions]. Valóság 12(5):69-74. 
Harlov-CSOrtán, Melinda

2018 Heritagizing the Countryside in Hungary. Acta Univ. Sapientiae, European and Regional Studies 13:19-35.

IsPÁn, Ágota Lídia

2019 Transformation of a Strictly Controlled Border Area into a Tourist Destination: Making Heritage in Communist Hungary. Traditiones 48(1):77-100.

Ispán, Ágota Lídia - BABAI, Dániel - MóD, László - UliCSNI, Viktor - MÉSzÁROs, Csaba

2018 Complex Ethnographic Research Methods for the Study of Protected Areas and Border Communities at the Slovenian-Hungarian Border. Acta Ethnographica Hungarica 63(2):471-500.

JÁvor, Kata - MolnÁr, Mária - Szabó, Piroska - SÁrkÁnY, Mihály

2000 A falusi társadalom a szocializmus időszakában [Village Society in the Socialist Era]. In PalÁdi-Kovács, Attila (ed.) Magyar néprajz VIII. Társadalom, 9771006. Budapest: Akadémiai.

KeLLER, Márkus

2019 A családi ház a magyar lakáspolitikában a második világháború után: transzfer, átvétel, hibridizáció [The Family House in Hungarian Housing Policy after the Second World War: Transfer, Reception, Hybridization]. Aetas 34(4):49-61.

Kocsis, Zsolt - LenNer, Tibor

2012 The national concept for settlement network development of 1971 and some Western European comparisons. In CsAPó, Tamás - BALOGH, András (eds.) Development of the Settlement Network in the Central European Countries: Past, Present, and Future, 75-91. Berlin - Heidelberg: Springer Verlag.

KomuÁthy, Attila

1985 Szalafö komplex védelme [The Complex Protection of Szalafö]. In Az Egri Nyári Egyetem elöadásai 1985. A népi építészet védelme, 89-91. Heves Megyei TIT - Országos Müemlékfelügyelőség.

Kovícs, Zsuzsa

2017 Kockaházak. Egy háztípus és benne egy falusi életforma felderitése Zala megyében a 20. század közepétöl napjainkig [Cube houses. The investigation of a house design and a rural lifestyle in Zala County from the middle of the $20^{\text {th }}$ century to the present day]. Doktori disszertáció. Budapest.

MÉszÁros, Csaba

2019 Flexible Boundaries at the Slovenian Raba Region. The Story of two Infrastructure Developments. Traditiones 48(1):233-250.

Molnár, Virág

2005 Cultural Politics and Modernist Architecture: The Tulip Debate in Postwar Hungary. American Sociological Review 70(1):111-135.

2010 In Search of the Ideal Socialist Home in Post-Stalinist Hungary: Prefabricated Mass Housing or Do-It-Yourself Family Home? Journal of Design History 23(1):61-81.

NAGY, László

1975 Hol a tulipán? [Where are the Tulips?] Élet és Irodalom, 1975. 10. 4:3.

PrakFalvi, Endre

2015 Háztűznéző. Epizódok a házhomlokzat díszítés XX. századi történetéből, különös tekintettel az úgynevezett kockaházakra [House Call. Episodes from 
the $20^{\text {th }}$-Century History of Facade Decoration, with Particular Regard to SoCalled Cube Houses]. Müemlékvédelem 59(5):286-301.

SÁRI, Zsolt

2009 Típusterves építkezések és az életmód átalakulásának kapcsolata [StandardDesign Constructions and the Transformation of Lifestyles]. In CSERI, Miklós - SÁRI, Zsolt (eds.) Vidéki életmódváltozások a 20. században, 21-52. Szentendre: Szabadtéri Néprajzi Múzeum.

TAMÁsKa, Máté

2008 Kockaházat a skanzenbe? Az utóparaszti háztípus helye a vidéki házfejlődésben [The Cube House as a Museum Piece? The Place of Post-Peasantry Dwelling Design in Rural Housing Development]. Múltunk 53(3):98-108.

2013 Falvak az uradalmak helyén. A megszünt nagybirtok telepes községeinek épitészete 1945 után [Manors Developed into Villages. The Architecture of Vanishing Manorial Colonies since 1945]. Budapest: Martin Opitz Kiadó.

Tóth, János

1966 A népi mủemléki és faluképi együttesek védelme Vas megyében [The protection of Folk Historic Building and Village Ensembles]. Vasi Szemle 20(3):91-103.

VALUCH, Tibor

2013 Magyar hétköznapok. Fejezetek a mindennapi élet történetéböl a második világháborútól az ezredfordulóig [Hungarian Weekdays. Chapters on the History of Everyday Life from the Second World War to the Turn of the Century]. Budapest: Napvilág.

Ágota Lídia Ispán is a research fellow at the Institute of Ethnology, Research Centre for the Humanities. She holds a PhD in Historical Science (Social and Economic History). Her research interests focus on the lifestyle changes in the framework of socialist modernization, the socialist city, history of everyday life, village power elite. E-mail: ispan.agota@btk.mta.hu

Open Access. This is an open-access article distributed under the terms of the Creative Commons Attribution 4.0 International License (https://creativecommons.org/licenses/by/4.0), which permits unrestricted use, distribution, and reproduction in any medium, provided the original author and source are credited, a link to the CC License is provided, and changes - if any - are indicated. (SID_1) 